\title{
Detection of Hermetia illucens by real-time PCR
}

\author{
A. Marien ${ }^{1 *}$, F. Debode ${ }^{1}$, C. Aerts ${ }^{1}$, C. Ancion ${ }^{1}$, F. Francis ${ }^{2}$ and G. Berben ${ }^{1}$ \\ ${ }^{1}$ Walloon Agricultural Research Center (CRA-W), Unit Traceability and Authentication, chaussée de Namur 24, 5030 \\ Gembloux, Belgium; ${ }^{2}$ Gembloux Agro-Bio Tech - University of Liège, Functional and Evolutionary Entomology, Passage \\ des Déportés 2, 5030 Gembloux, Belgium; a.marien@cra.wallonie.be
}

Received: 31 October 2017 / Accepted: 1 March 2018

(c) 2018 Wageningen Academic Publishers

\section{RESEARCH ARTICLE}

\begin{abstract}
Insects are rich in proteins and could be an alternative source of macronutrients to feed animals and humans. Over the past few years, numerous companies have started producing insects for feed purposes. In Europe, the processed animal proteins obtained from seven insect species have been authorised for aquaculture by Commission Regulation (EU) 2017/893 since 1 July 2017. Methods of authentication are required to check the conformity of the products. In this study, we propose a real-time PCR method for the specific detection of the black soldier fly (Hermetia illucens L.), one of the most widely used insects for feed production. The developed PCR assays amplify a $67 \mathrm{bp}$ fragment based on the mitochondrial COX3 gene coding for subunit 3 of the cytochrome c oxidase. The qualitative method was tested according to several performance criteria. The specificity was tested against 51 insect species. The specificity was also checked against plant species and other animal species such as crustaceans, mammals and birds. The sensitivity, efficiency and robustness of the PCR test were successfully tested. The applicability of the test was proven through the analysis of real-life processed samples (industrial meals) of $H$. illucens.
\end{abstract}

Keywords: insect, Hermetia illucens, black soldier fly, detection, real-time PCR

\section{Introduction}

Farmed production of fish and shellfish nearly tripled in volume between 1995 and 2007 leading to an increase in demand for fish feed by the aquaculture sector (Naylor et al., 2009). Fishmeal has been the usual source of animal protein to feed farmed fish for several decades. As fishmeal is becoming a finite resource, the aquaculture industry is searching for new alternative sources of high quality proteins (Riddick, 2014). Insect meal from Diptera could be one of the possible alternatives (Barroso et al., 2014). The high protein and fat content of dried black soldier fly prepupae reinforces the high potential of fly meal as animal feed (Diener et al., 2009). The processed animal proteins from seven insects were authorised in aquafeed in Europe by Commission Regulation (EU) 2017/893 on 1 July 2017 (EC, 2017). Insect-rearing for commercial purposes exists both inside and outside Europe. The most promising insect species for industrial production of feed are black soldier fly (Hermetia illucens), the common house fly (Musca domestica), the yellow mealworm (Tenebrio molitor), the lesser mealworm (Alphitobius diaperinus), and several cricket species (Acheta domesticus, Gryllodes sigillatus, Gryllus assimilis) (EC, 2017; Van Huis, 2012).

The identification of insect species in feed products is therefore an emerging application. DNA-based methods have generally been used for taxonomic classifications (Cameron, 2014; Cook et al., 2002; Hebert et al., 2003; Mandal et al., 2014), forensic entomology (Dawnay et al., 2007; Malewski et al., 2010; Wells and Škaro, 2014), and predation (Hoogendoorn and Heimpel, 2001; Pons, 2006; Pons et al., 2006; Sheppard et al., 2005). Recently, methods by real-time PCR were proposed for the detection of $T$. molitor in food and feed (Debode et al., 2017a). Presently, real-time PCR remains the reference technique for the detection of DNA in food or feed products. For a detection in processed products, the amplicon size must be small (Debode et al., 2007, 2017b). This study proposes a realtime PCR method for the specific detection of the black soldier fly (H. illucens). 


\section{Materials and methods}

\section{Samples}

Insects were collected in the environment or provided by the Functional and Evolutionary Entomology unit of Gembloux Agro-Bio Tech (ULiège, Gembloux, Belgium). Insects were selected in order to cover several taxonomic groups.

Real-life processed samples (industrial meals from different EU-based companies) of $H$. illucens were obtained through the International Producers of Insects for Food and Feed (IPIFF). For each H. illucens industrial meal, a mix containing $0.1 \%$ (in mass fraction) of $H$. illucens in a commercial fish feed (composition: fishmeal, fish oil, wheat gluten, protein concentrate extracted from pea, maize starch, yeast, lecithin, vitamins and minerals) was prepared.

\section{DNA extraction}

Genomic DNA was extracted and purified from all samples following the CTAB-based method described in Annex A.3.1 of the international standard ISO 21571:2005 (ISO, 2005). The quality and quantity of DNA extracted from samples were estimated spectrophotometrically using a Nanodrop ND-1000 spectrophotometer at $260 \mathrm{~nm}$ (A260) and $280 \mathrm{~nm}$ (A280) absorbance (Nanodrop Technologies, Wilmington, NC, USA). DNA purity was determined using the A260/A280 ratio. The amplifiability of the DNA extract was checked by real-time PCR with the $18 \mathrm{~S}$ target for insects (Debode et al., 2017a) and rbcL (Debode et al., 2012) for plants. Other species were tested with targets developed or evaluated within the framework of the European Union Reference Laboratory for Animal Proteins in feedingstuff activities (EURL-AP, 2013, 2014a) or with 18S target (Debode et al., in press; Garikipati et al., 2006). Ten ng of DNA were used in the PCR reactions.

The industrial meals and the mixes at $0.1 \%$ of $H$. illucens were extracted following the method recommended by EURL-AP and based on the adaptation of the protocol of the Wizard Magnetic DNA Purification System for Food kit (Promega, Madison, WI, USA). This method is described in the EURL-AP Standard Operating Procedure (EURLAP, 2014b).

\section{Primers and probe for the real-time PCR}

Eurogentec (Seraing, Belgium) synthesised the primers and probes. The primers and probe sequences developed for the detection of $H$. illucens are presented in Table 1 . The probe for this latter method was labelled with the reporter dye FAM ${ }^{\mathrm{TM}}$ (6-carboxyfluorescein) at the 5' end and the quencher dye TAMRA ${ }^{\mathrm{Tm}}$ (tetramethyl-6-carboxyrhodamine) at the 3 ' end.

\section{Real-time PCR method}

Real-time PCR (total reaction volume of $25 \mu \mathrm{l}$ ) was performed on an ABI7500 Fast (Thermo Fisher, Foster City, CA, USA) using the Universal Master Mix of Diagenode (Seraing). The reaction mixture included $12.5 \mu$ l of Master Mix, $1.7 \mu$ lof each primer $(5 \mu \mathrm{M}), 1.5 \mu \mathrm{l}$ of probe $(9 \mu \mathrm{M}), 2.6$ $\mu \mathrm{l}$ of bidistilled water, and $5 \mu \mathrm{l}$ of DNA. Reaction mixtures were distributed on 96-well reaction plates (Thermo Fisher) developed for the specific thermocyclers. Wells were covered with adhesive film and centrifuged ( $2 \mathrm{~min}$ at $500 \mathrm{rpm}$ ) to eliminate any air bubbles in the well bottoms. The thermal programme was as follows: $2 \mathrm{~min}$ at $50{ }^{\circ} \mathrm{C} ; 10$ min at $95^{\circ} \mathrm{C} ; 50$ cycles of $15 \mathrm{~s}$ at $95^{\circ} \mathrm{C}$; and $1 \mathrm{~min}$ at $50^{\circ} \mathrm{C}$.

\section{Specificity of the PCR method}

The specificity of the method was checked on 51 insect species of different taxonomic orders including nine Diptera other than H. illucens, eighteen Coleoptera, seven Orthoptera, five Hemiptera, six Hymenoptera, three Lepidoptera, one Nevroptera, one Dermaptera and one Blattodea. The specificity tests were performed on five crustaceans (also members, as insects, of the Arthropoda phylum), one mollusc and nine other animal species (six mammals, two birds, one fish). As insect meals, the meals produced from these animal species are considered by the legislation as processed animal protein (PAP), and could be found in PAP used to feed animals. The possibility of a cross-reaction with human DNA was envisaged too. Seven plant species were also tested and correspond for the most part to plant species frequently used in feed (Table 2). Ten ng of DNA were used in the PCR reactions. Each DNA extract was tested at least in duplicate.

Table 1. Primers and probe used for the Hermetia illucens detection by real-time PCR.

$\begin{array}{llll}\text { Target } & \text { Name } & \text { Sequences 5'-3' } & \text { Amplicon size (bp) } \\ \text { H. illucens } & \text { HI-mito-2F } & \text { ACCATTCTTCAAGCCTATGA } & 67 \\ & \text { HI-mito-2R } & \text { TTGAGCCGTAGACTGCG } & \\ & \text { HI-mito-P } & \text { FAM-TGAAGCCCCTTTTACTATTGCTG-TAMRA } & \end{array}$


Table 2. Specificity of Hermetia illucens PCR test on animal and plant species $(n \geq 2)$. For positive samples mean quantification cycle $(\mathrm{Cq})$ values $(\mathrm{m})$ and standard deviations $(\sigma)$ are given in brackets. ${ }^{1}$

\begin{tabular}{|c|c|c|c|c|}
\hline & Taxonomic classification & Latin name or family & Common name & Results \\
\hline \multirow[t]{51}{*}{ Insects } & Diptera & Hermetia illucens L. & black soldier fly & $+(m=13.02, \sigma=0.20)$ \\
\hline & & Stomoxys calcitrans $\mathrm{L}$. & stable fly & - \\
\hline & & Tabanus sp. & horse fly & - \\
\hline & & Bibio marci L. & St. Mark's fly & - \\
\hline & & Calliphora vicina R.-D. & blow fly & $+(m=36.06, \sigma=0.48)$ \\
\hline & & Sarcophaga carnaria L. & common fresh fly & - \\
\hline & & Bombylius major $\mathrm{L}$. & large bee-fly & - \\
\hline & & Chironomus plumosus $\mathrm{L}$. & buzzer midge & - \\
\hline & & Syrphidae & hover fly & - \\
\hline & & Musca domestica L. & house fly & - \\
\hline & Orthoptera & Locusta migratoria L. & migratory locust & - \\
\hline & & Acheta domesticus $\mathrm{L}$. & house cricket & - \\
\hline & & Gryllus bimaculatus De G. & Mediterranean field cricket & - \\
\hline & & Gryllus assimilis $\mathrm{F}$. & Jamaican field cricket & - \\
\hline & & Gryllus sp. & cricket & - \\
\hline & & Locusta sp. & locust & - \\
\hline & & Acheta sp. & cricket & - \\
\hline & Coleoptera & Pachnoda sp. & dola's worm & - \\
\hline & & Tenebrio molitor L. & mealworm & - \\
\hline & & Zophobas morio $\mathrm{F}$. & superworm & - \\
\hline & & Alphitobius diaperinus $\mathrm{P}$. & lesser mealworm & - \\
\hline & & Carabus sp. & beetle & _- \\
\hline & & Staphylinidae & rove beetles & _- \\
\hline & & Curculionidae/Scolytidae & true weevils & - \\
\hline & & Coccinellidae & ladybird & _- \\
\hline & & Scarabidae & scarab beetles & - \\
\hline & & Oxythyrea funesta $\mathrm{P}$. & white-spotted rose beetle & - \\
\hline & & Melolontha melolontha L. & cockchafer & - \\
\hline & & Leptinotarsa decemlineata S. & colorado potato beetle & - \\
\hline & & Cassida viridis $\mathrm{L}$. & green tortoise beetle & $+(m=37.66, \sigma=0.39)$ \\
\hline & & Cicindela campestris $\mathrm{L}$. & green tiger beetle & $+(m=40.64, \sigma=0.55)$ \\
\hline & & Nicrophorus humator G. & black sexton beetle & - \\
\hline & & Nicrophorus vespillo L. & common burying beetle & - \\
\hline & & Cetonia aurata L. & rose chafer & - \\
\hline & Hemiptera & Aphididae & aphid & - \\
\hline & & Anthocoridae & bugs & - \\
\hline & & Palomena prasina $\mathrm{L}$. & green shield bug & - \\
\hline & & Pyrrhocorus apterus L. & firebug & - \\
\hline & & Psyllus sp. & jumping plant louse & - \\
\hline & Hymenoptera & Apis sp. & bee & - \\
\hline & & Bombus terrestris $\mathrm{L}$. & buff-tailed bumblebee & - \\
\hline & & Bombus campestris $\mathrm{P}$. & field cuckoo bumblebee & - \\
\hline & & Componotus sp. & carpenter ant & - \\
\hline & & Vespa sp. & hornet & - \\
\hline & & Vespula sp. & wasp & - \\
\hline & Lepidoptera & Biston betularia L. & peppered moth & - \\
\hline & & Tineola sp. & moth & - \\
\hline & & Bombyx mori L. & silkworm & - \\
\hline & Neuroptera & Chrysoperla carnea S. & green lacewing & - \\
\hline & Blattodea & Blatta orientalis $\mathrm{L}$. & oriental cockroach & - \\
\hline & Dermaptera & Forficula auricularia L. & common earwig & - \\
\hline
\end{tabular}


Table 2. Continued.

\begin{tabular}{|c|c|c|c|c|}
\hline & Taxonomic classification & Latin name or family & Common name & Results \\
\hline \multirow[t]{5}{*}{ Crustacean } & & Euphausia superba D. & Antartic krill & - \\
\hline & & Penaeus vannamei $\mathrm{B}$. & whiteleg shrimp & - \\
\hline & & Nephrops norvegicus L. & langoustine & - \\
\hline & & Homarus gammarus $\mathrm{L}$. & European lobster & - \\
\hline & & Paralithodes camtschatieus T. & red king crab & - \\
\hline Mollusca & & Teuthida sp. & squid & - \\
\hline \multirow[t]{6}{*}{ Mammals } & & Bos taurus L. & beef & - \\
\hline & & Sus scrofa L. & pork & - \\
\hline & & Ovis aries $\mathrm{L}$. & sheep & - \\
\hline & & Equus caballus $\mathrm{L}$. & horse & - \\
\hline & & Equus asinus $\mathrm{L}$. & donkey & - \\
\hline & & Homo sapiens L. & human & - \\
\hline Fish & & Salmo salar L. & salmon & - \\
\hline \multirow[t]{2}{*}{ Birds } & & Gallus gallus L. & chicken & - \\
\hline & & Meleagris gallopavo L. & turkey & - \\
\hline \multirow[t]{7}{*}{ Plants } & & Glycine max M. & soybean & - \\
\hline & & Zea mays L. & maize & - \\
\hline & & Brassica rapa L. & rapeseed & - \\
\hline & & Triticum aestivum $\mathrm{L}$. & wheat & - \\
\hline & & Oryza sativa L. & rice & - \\
\hline & & Solanum lycopersicum L. & tomato & - \\
\hline & & Beta vulgaris L. & sugar beet & - \\
\hline
\end{tabular}

\section{Cloning into pCR2.1 and dilutions}

The $67 \mathrm{bp}$ amplified fragment from H. illucens was ligated into the $3.9 \mathrm{~kb} \mathrm{pCR}^{\circ} 2.1$-TOPO plasmid vector (Invitrogen, Merelbeke, Belgium) following the $\mathrm{TOPO}^{\oplus} \mathrm{TA}^{\mathrm{T}}$ Cloning ${ }^{\circledR}$ kit instructions (Invitrogen). Plasmid DNA was isolated from bacterial cultures using the Genopure Plasmid Maxi Kit (Roche Diagnostics GmbH, Mannheim, Germany). The plasmid DNA was linearized with the HindIII restriction enzyme (Promega) and then purified using phenolchloroform-isoamyl alcohol.

The quantity and quality of plasmid DNA were measured using a Nanodrop ND-1000 spectrophotometer at 260 $\mathrm{nm}$ (A260) and $280 \mathrm{~nm}$ (A280) absorbance. DNA purity was determined using A260/A280 ratio. The quantity of plasmid DNA was converted to copy number as follows: firstly, taking into consideration that 1 unit of absorbance at $260 \mathrm{~nm}$ corresponds to a concentration of $50 \mu \mathrm{g} / \mathrm{ml}$; secondly, that the molar weight of one plasmid molecule is derived from the combination of its size in base pairs and the mean molar weight of one base pair set at $635 \mathrm{Da}$ (Sambrook et al., 1989); and thirdly, by knowing the number of moles available, it is possible to deduce the copy number of plasmids by means of the Avogadro number (Debode, 2017; Debode et al., 2010).

The sensitivity, efficiency and robustness of the PCR test were determined on diluted plasmid DNA. These dilutions were realised in water until an estimated copy number of 10,000 copies/ $5 \mu \mathrm{l}$ was reached. Higher dilutions were done in a solution containing $5 \mathrm{ng} / \mu \mathrm{l}$ of organic maize DNA as background DNA. Low binding tubes were chosen to minimise DNA losses due to tube wall binding.

\section{Determination of the limit of detection}

Target sensitivity was evaluated following the recommendations of the former AFNOR XP V03-020-2 standard (AFNOR, 2008). This standard no longer exists, but the principles detailed in it are still valid. The absolute limit of detection (LOD) was determined for the PCR assay (primers + probe + amplification programme) on dilutions of plasmid material.

The subsequent dilutions had to contain 50, 20, 10, 5, 2, 1 and 0.1 copies of the target. Six PCRs had to be achieved for each dilution. The method's $\mathrm{LOD}_{6}$ was the smallest copy number for which the six PCRs were positive, and only 
if the final dilution supposed to contain the 0.1 copy per reaction generated a maximum of one positive PCR signal on the six replications. If more than one positive signal was observed for the 0.1 copy then, the DNA quantities had to be revised. The copy number corresponding to $\mathrm{LOD}_{6}$ is then tested 60 times on the same plate (determination of the $\left.\mathrm{LOD}_{95 \%}\right)$. The $\mathrm{LOD}_{95 \%}$ is validated if at least $95 \%$ of positive signals are recorded out of the 60 replicates. The highest acceptable copy numbers for $\mathrm{LOD}_{6}$ and $\mathrm{LOD}_{95 \%}$ are 20 copies.

\section{Determination of the efficiency}

The efficiency of the PCR assay was calculated with a dilution series of plasmid material at target levels of 5,000, 2,500, 1000, 500 and 100 copies. Each dilution was analysed in 6 replicates and on 4 runs. The efficiency has to be between 80 and 120\% (Broeders et al., 2014).

\section{Robustness of the PCR method}

The robustness of the method was tested by introducing some slight deviations to the standard experimental conditions (Broeders et al., 2014; CCMAS, 2010; Debode et al., 2017c) such as the annealing temperature $\left(50 \pm 1{ }^{\circ} \mathrm{C}\right)$, the primer concentrations (standard or reduced by $30 \%$ ), the probe concentration (standard or reduced by $30 \%$ ) and the real-time PCR master mix volume (standard or $\pm 1 \mu$ l) which involves a final reaction volume of $25 \pm 1 \mu$ l. Six replicates of the plasmid borne target at 20 copies $/ 5 \mu$ l were tested in the conditions described in Table 3 . The robustness was performed on two real-time PCR platforms: thermocycler ABI7500 Fast (Thermo Fisher) with Universal Mastermix by Diagenode (Seraing) and thermocycler Lightcycler 480 (Roche Diagnostics Ltd., Rotkreuz, Switzerland) with ABI Taqman 2x Universal PCR Mastermix (Thermo Fisher). The acceptance criterion is that all deviations to the standard protocol must give a positive result at a level of 20 copies of the target (Broeders et al., 2014).

\section{Applicability of the PCR method}

The applicability of the PCR method was checked on four real-life processed samples (industrial meals) of $H$. illucens produced in the EU. The DNA extract of each meal was tested by PCR in triplicate.

The sensitivity of the PCR assay was also evaluated on a fish feed containing $0.1 \%$ in mass fraction of $\mathrm{H}$. illucens industrial meal. Two DNA extracts with 2 dilutions were tested by PCR in triplicate.

\section{Results and discussion}

Presently, only a few DNA sequences are available for H. illucens in the National Center for Biotechnology Information database and the DNA Data Bank of Japan. Therefore, several problems were met to select regions of interest: firstly, even for mitochondrial DNA, which is generally better referenced for animal species, only partial sequences were available prior to June 2017; secondly, when alignments were possible, they showed numerous similarities with other insect species and sometimes even with unexpected species (e.g. for some regions, there were greater similarities with crustacean species than with insect species); and thirdly, some regions of interest were AT-rich, preventing their use in primers and probes if the recommended GC content or length has to be met (Debode et al., 2017b; Rodriguez et al., 2015). Therefore, the COX3 gene coding for subunit 3 of cytochrome c oxydase (mitochondrial DNA) was used to select the primers and probe. Working on mitochondrial DNA can be an advantage for detection as a mitochondrion contains several copies of its genome and several mitochondria can be present in a single cell (Cavelier et al., 2000). However, this multicopy characteristic is a disadvantage for quantitation purposes as the copy number per cell will be variable depending on the considered tissue.

Table 3. Experimental conditions tested to evaluate the robustness of the described Hermetia illucens PCR test.

\begin{tabular}{|c|c|c|c|c|c|}
\hline PCR machine & \multicolumn{5}{|c|}{ ABI7500 fast (Life Technologies) and Lightcycler 480 (Roche Diagnostics Ltd) } \\
\hline PCR reagent kit & \multicolumn{5}{|c|}{ Universal Mastermix (Diagenode s.a.) and ABI Taqman 2x Universal PCR Master mix (Life technologies) } \\
\hline Annealing temperature & \multicolumn{5}{|l|}{49 and $51^{\circ} \mathrm{C}$} \\
\hline Primer concentration & Minus $30 \%$ & Standard & Standard & Standard & Standard \\
\hline Probe concentration & Standard & Minus $30 \%$ & Standard & Standard & Standard \\
\hline PCR volume & Standard & Standard & $\begin{array}{l}\text { Standard } \\
(20 \mu \mathrm{l} \mathrm{mix}+5 \mu \mathrm{l} \text { DNA })\end{array}$ & $\begin{array}{l}\text { Standard }+1 \mu \text { l Mastermix } \\
(21 \mu \mathrm{l} \text { mix }+5 \mu \mathrm{l} \text { DNA })\end{array}$ & $\begin{array}{l}\text { Standard - } 1 \mu \mathrm{l} \text { Mastermix } \\
(19 \mu \mathrm{l} \text { mix }+5 \mu \mathrm{l} \text { DNA })\end{array}$ \\
\hline
\end{tabular}


The specificity was tested on DNA from H. illucens but also on 50 other non-target insect species, including nine Diptera. Positive results were obtained with $\mathrm{H}$. illucens. On the 50 other insect species, late signals were observed with Calliphora vicina (Diptera), Cassida viridis and Cicindela campestris (Coleoptera). These aspecificities should not cause problems because the amplification signals are late (see Cq values in Table 2). Moreover they were not reproducible during a second analysis. No signal was obtained with the 15 other animal species (vertebrates, mollusc and crustaceans) and the seven plant species tested. The results are presented in Table 2. As it was hard to obtain individuals of the Stratiomyidae family identified with certainty, the black soldier fly was the only representative of Stratiomydae family. However, on the eight other Diptera tested, six species belong to the Brachycera suborder like H. illucens. In the current EU legislation, only two Diptera species are authorised in fish feed and can be produced at large scale. The specificity tests also consider this second authorised Diptera, $M$. domestica, which in practice could be mixed with $H$. illucens in meals.

Since the COX3 gene is a multicopy target, sensitivity, efficiency and robustness were performed on the target in their plasmid DNA in order to have better control of the copy number. These three parameters reached the recommended acceptance criteria. Indeed, for the sensitivity, the $\mathrm{LOD}_{6}$ was estimated at 5 copies following the AFNOR XP V03-020-2 standard approach (AFNOR, 2008 ) and for the $\mathrm{LOD}_{95 \%}$, tested at the 5 copies level, $60 / 60$ positive signals were obtained with a mean $\mathrm{Cq}$ value of 36.82 . Therefore, the PCR test easily reaches the recommended performance criteria ( $\leq 20$ copies). The PCR efficiency was evaluated at $92.7 \%$. The Table 4 presents the mean $\mathrm{Cq}$ values obtained with different copy numbers tested (from 5,000 to 5). When calculated per plate, the efficiency was always higher than $90 \%$ and therefore met the acceptance criterion set by Broeders et al. (2014). The robustness of the PCR method was also positively evaluated. All tested deviations to the standard protocol delivered positive results at a target copy number of 20 in the PCR.

Positive signals were also obtained on industrial samples (pure meals of H. illucens) showing the applicability of the PCR test on real-life samples (Table 5). The four mixes of

Table 4. Quantification cycle $(\mathrm{Cq})$ values obtained on dilutions of plasmid material used for efficiency calculation and for $\mathrm{LOD}_{95 \%}$. For efficiency, each concentration was analysed in 6 replicates and on 4 PCR plates $(n=24)$. For $L^{2} D_{95 \%}$, the concentration at 5 copies was analysed in 60 replicates on 1 PCR plate $(n=60)$.

$\begin{array}{rll}\begin{array}{l}\text { Copy number of } \\ \text { target }\end{array} & \mathrm{Cq} \text { (mean value) } & \begin{array}{l}\text { Standard deviation } \\ \text { and }(\mathrm{n})\end{array} \\ 5,000 & 26.75 & 0.21(24) \\ 2,500 & 27.78 & 0.18(24) \\ 1000 & 29.07 & 0.17(24) \\ 500 & 30.15 & 0.14(24) \\ 100 & 32.72 & 0.27(24) \\ 5 & 36.82 & 0.72(60)\end{array}$

Table 5. Quantification cycle $(\mathrm{Cq})$ mean values obtained with the Hermetia illucens PCR test on processed samples from $\mathrm{H}$. illucens and on mixes containing $0.1 \%$ in mass fraction of $H$. illucens in a commercial fish feed $(n=3)$.

\begin{tabular}{|c|c|c|c|c|}
\hline \multirow[t]{2}{*}{ Identification of samples } & & & \multicolumn{2}{|l|}{$\mathrm{Cq}$} \\
\hline & & & Dilution $1 \mathrm{x}$ & Dilution 10x \\
\hline \multirow[t]{8}{*}{ Pure industrial meals of $H$. illucens produced in the EU } & \multirow[t]{2}{*}{$n^{\circ} 1$} & Extract 1 & 15.32 & 18.83 \\
\hline & & Extract 2 & 15.33 & 18.71 \\
\hline & \multirow[t]{2}{*}{$n^{\circ} 2$} & Extract 1 & 13.73 & 17.14 \\
\hline & & Extract 2 & 13.40 & 17.12 \\
\hline & \multirow[t]{2}{*}{$n^{\circ} 3$} & Extract 1 & 13.97 & 17.18 \\
\hline & & Extract 2 & 14.04 & 17.56 \\
\hline & \multirow[t]{2}{*}{$n^{\circ} 4$} & Extract 1 & 13.16 & 16.26 \\
\hline & & Extract 2 & 14.08 & 16.61 \\
\hline \multirow[t]{2}{*}{ Fish feed containing $0.1 \%$ of $H$. illucens from the industrial meal $n^{\circ} 1$} & & Extract 1 & 26.90 & 29.05 \\
\hline & & Extract 2 & 26.99 & 28.46 \\
\hline \multirow[t]{2}{*}{ Fish feed containing $0.1 \%$ of $H$. illucens from the industrial meal $n^{\circ} 2$} & & Extract 1 & 26.51 & 27.98 \\
\hline & & Extract 2 & 27.05 & 28.20 \\
\hline \multirow[t]{2}{*}{ Fish feed containing $0.1 \%$ of $H$. illucens from the industrial meal $n^{\circ} 3$} & & Extract 1 & 28.23 & 28.51 \\
\hline & & Extract 2 & 27.22 & 28.50 \\
\hline \multirow[t]{2}{*}{ Fish feed containing $0.1 \%$ of $H$. illucens from the industrial meal $n^{\circ} 4$} & & Extract 1 & 27.33 & 27.99 \\
\hline & & Extract 2 & 27.54 & 28.09 \\
\hline
\end{tabular}


fish feed containing $0.1 \%$ of different processed $H$. illucens meals were also tested. All the PCR tests gave positive results (Table 5). The tenfold dilutions provide evidence of a slight inhibitory effect of feed on the amplification of the $H$. illucens target. On the one hand, the complete fish feed used was checked to see if it was free of the $H$. illucens target before its spiking with black soldier fly meal. On the other hand, the 18S target (Debode et al., in press; Garikipati et al., 2006) provided evidence of the amplifiability of DNA from DNA extracts of this feed.

\section{Conclusions}

The PCR method for the detection of $H$. illucens based on the COX3 gene coding for subunit 3 of the cytochrome $\mathrm{c}$ oxidase is fit for purpose. This qualitative PCR test is based on mitochondrial DNA, consequently, it is a multicopy target which allows detection at low level even on processed samples. The specificity gives good results with respect to the insect, animal and plant species tested. Only three insect species showed aspecificities. However, the signals with these non-target species are late and not reproducible. The risk of interference is extremely reduced when considering the aim for which the test is designed and the earliest signal is in fact close to the LOD. The acceptance criteria were reached for sensitivity $\left(\mathrm{LOD}_{6}\right.$ and $\left.\mathrm{LOD}_{95 \%}\right)$, efficiency and robustness. The PCR method is also applicable to real-life samples from industry even when used at $0.1 \%$ in mass fraction in fish feed.

\section{Acknowledgements}

The authors would like to thank Julien Maljean and Denis Roulez (of the Molecular biology team, Unit 16, CRA-W), and Amaury Gérard (student at ULiège Gembloux Agro-Bio Tech, Gembloux, Belgium) for their technical help. They would also like to thank the International Producers of Insects for Food and Feed (IPIFF) for the industrial meals provided.

\section{Competing interests}

The authors declare that they have no competing interests.

\section{References}

Association française de Normalisation (AFNOR), 2008. Détection et quantification des organismes végétaux génétiquement modifiés et produits dérivés. Partie 2: méthodes basées sur la réaction de polymérisation en chaîne. AFNOR Standard XP-V-03-020-2. AFNOR, Saint-Denis La Plaine, France.

Barroso, F.G., De Haro, C., Sánchez-Muros, E.V., Martinez-Sánchez, A. and Pérez-Banón, C., 2014. The potential of various insect species for use as food for fish. Aquaculture 422-423: 193-201.
Broeders, S., Huber, I., Grohmann, L., Berben, G., Taverniers, I., Mazzara, M., Roosens, N. and Morisset, D., 2014. Guidelines for validation of qualitative real-time PCR methods. Trends in Food Science \& Technology 37: 115-126.

Cameron, S.L., 2014. Insect mitochondrial genomics: implications for evolution and phylogeny. Annual Review of Entomology 59: 95-117.

Cavelier, L., Johannisson, A. and Gyllensten, U., 2000. Analysis of mtDNA copy number and composition of single mitochondrial particles using flow cytometry and PCR. Experimental Cell Research 259: 79-85.

Codex Committee on Methods of Analysis and Sampling (CCMAS), 2010. Guidelines on performance criteria and validation of methods for detection, identification and quantification for specific DNA sequences and specific proteins in foods. Report No. CAC/GL 74-2010. CCMAS, Rome, Italy. Available at: https://tinyurl.com/ ydx8uak6.

Cook, L.G., Gullan, P.J. and Trueman, H.E., 2002. A preliminary phylogeny of the scale insects (Hemiptera: Sternorrhyncha: Coccoidea) based on nuclear small-subunit ribosomal DNA. Molecular Phylogenetics and Evolution 25: 43-52.

Dawnay, N., Ogden, R., McEwing, R., Carvalho, G.R. and Thorpe, R.S., 2007. Validation of the barcoding gene COI for use in forensic genetic species identification. Forensic Science International 173: 1-6.

Debode, F., 2017. Développement de méthodologies pour la détection des plantes génétiquement modifiées. PhD thesis, Université Catholique de Louvain, Belgium, 391 pp. Available at: http://hdl. handle.net/2078.1/186329.

Debode, F., Janssen, E. and Berben, G., 2007. Physical degradation of genomic DNA of soybean flours does not impair relative quantification of its transgenic content. European Food Research and Technology 226: 273-280.

Debode, F., Janssen, E., Bragard, C. and Berben, G., 2017c. Detection by real-time PCR and pyrosequencing of the $c r y 1 \mathrm{Ab}$ and $c r y 1 \mathrm{Ac}$ genes introduced in GM constructions. Food Additives and Contaminants: part A 34: 1398-1409.

Debode, F., Janssen, E., Marien, A. and Berben, G., 2012. DNA detection by conventional and real-time PCR after extraction from vegetable oils. Journal of the American Oil Chemists' Society 89: 1249-1257.

Debode, F., Janssen, E., Marien, A., Devlin, R.H., Lieske, K., Mankertz, J. and Berben, G., in press. Detection of transgenic Atlantic and Coho salmon by real-time PCR. Food Analytical Methods, https:// doi.org/10.1007/s12161-018-1214-1.

Debode, F., Marien, A., Gérard, A., Francis, F., Fumière, O. and Berben, G., 2017a. Development of real-time PCR targets for the detection of Tenebrio molitor in food and feed. Food Additives \& Contaminants: part A 34: 1421-1426.

Debode, F., Marien, A., Janssen, E. and Berben, G., 2010. Design of multiplex calibrant plasmids, their use in GMO detection and the limit of their applicability for quantitative purposes owing to competition effects. Analytical and Bioanalytical Chemistry 396: 2151-2164.

Debode, F., Marien, A., Janssen, E., Bragard, C. and Berben, G., 2017b. The influence of amplicon length on real-time PCR results. Biotechnologie, Agronomie, Société et Environnement 21: 3-11. 
Diener, S., Zurbrügg, C. and Tockner, K., 2009. Conversion of organic material by black soldier fly larvae: establishing optimal feeding rates. Waste Management \& Research 27: 603-610.

European Union Reference Laboratory for Animal Proteins in feedingstuff (EURL-AP), 2013. Detection of horse DNA using real-time PCR. EURL-AP, Gembloux, Belgium. Available at: https:// tinyurl.com/y7o4dtse.

European Union Reference Laboratory for Animal Proteins in feedingstuff (EURL-AP), 2014a. Detection of ruminant DNA in feed using real-time PCR. EURL-AP, Gembloux, Belgium. Available at: https://tinyurl.com/y9nycxvb.

European Union Reference Laboratory for Animal Proteins in feedingstuff (EURL-AP), 2014b. DNA extraction using the 'Wizard Magnetic DNA purification system for food' kit. EURLAP, Gembloux, Belgium. Available at: https://tinyurl.com/ycjxqlgp. European Commission (EC), 2017. Commission regulation (EU) 2017/893 of 24 May 2017 amending Annexes I and IV to Regulation (EC) No 999/2001 of the European Parliament and of the Council and Annexes X, XIV and XV to Commission Regulation (EU) No $42 / 2011$ as regards the provisions on processed animal protein. EC, Brussels, Belgium. Available at: https://tinyurl.com/ycu9yrkk.

Garikipati, D.K., Gahr, S.A. and Rodgers, B.D., 2006. Identification, characterization, and quantitative expression analysis of rainbow trout myostatin-1a and myostatin-1b genes. Journal of Endocrinology 190: 879-888.

Hebert, P.D., Ratnasingham, S. and De Waard, J.R., 2003. Barcoding animal life: cytochrome c oxidase subunit 1 divergences among closely related species. Proceedings of the Royal Society of London B: Biological Sciences 270: S96-S99.

Hoogendoorn, M. and Heimpel, G.E., 2001. PCR-based gut content analysis of insect predators: using ribosomal ITS-1 fragments from prey to estimate predation frequency. Molecular Ecology 10: 20592067.

International Organisation for Standardization (ISO), 2005. ISO 21571:2005. Foodstuffs - methods of analysis for the detection of genetically modified organisms and derived products - nucleic acid extraction. ISO, Geneva, Switzerland.
Malewski, T., Draber-Mońko, A., Pomorski, J., Łoś, M. and Bogdanowicz, W., 2010. Identification of forensically important blowfly species (Diptera: Calliphoridae) by high-resolution melting PCR analysis. International Journal of Legal Medicine 124: 277-285.

Mandal, S.D., Chhakchhuak, L., Gurusubramanian, G. and Kumar, N.S., 2014. Mitochondrial markers for identification and phylogenetic studies in insects - a review. DNA Barcodes 2: 1-9.

Naylor, R.L., Hardy, R.W., Bureau, D.P., Chiu, A., Elliott, M., Farrell, A.P., Forster, I., Gatlin, D.M., Goldburg, R.J., Hua, K. and Nichols, P.D., 2009. Feeding aquaculture in an era of finite resources. Proceedings of the National Academy of Sciences of the USA 106: 15103-15110.

Pons, J., 2006. DNA-based identification of preys from non-destructive, total DNA extractions of predators using arthropod universal primers. Molecular Ecology Notes 6: 623-626.

Pons, J., Barraclough, T.G., Gomez-Zurita, J., Cardoso, A., Duran, D.P., Hazell, S., Kamoun, S., Sumlin, W.D. and Vogler, A.P., 2006. Sequence-based species delimitation for the DNA taxonomy of undescribed insects. Systematic Biology 55: 595-609.

Riddick, E., 2014. Insect protein as a partial replacement for fishmeal in the diets of juvenile fish and crustaceans. In: Morales-Ramos, J.M., Rojas, M.G. and Shapiro-Ilan, D. (eds.) Mass production of beneficial organisms. Elsevier, New York, NY, USA, pp. 565-579.

Rodriguez, A., Rodriguez, M., Córdoba, J.J. and Andrade, M.J., 2015. Design of primers and probes for quantitative real-time PCR methods. Methods in Molecular Biology 1275: 31-56.

Sambrook, J., Fritsch, E.F. and Maniatis, T., 1989. Molecular cloning. A laboratory manual ( $2^{\text {nd }}$ Ed.). Cold Spring Harbor Laboratory Press, Cold Spring Harbor, NY, USA.

Sheppard, S.K., Bell, J., Sunderland, K.D., Fenlon, J., Skervin, D. and Symondson, W.O.C., 2005. Detection of secondary predation by PCR analyses of the gut contents of invertebrate generalist predators. Molecular Ecology 14: 4461-4468.

Van Huis, A., 2012. Potential of insects as food and feed in assuring food security. Annual Review of Entomology 58: 563-583.

Wells, J.D. and Škaro, V., 2014. Application of DNA-based methods in forensic entomology. In: Primorac, D. and Schanfield, M. (eds.) Forensic DNA applications: an interdisciplinary perspective. CRC Press, Boca Raton, FL, USA. 